\title{
Haemopoietic cell transplants, corneal transplants and champagne
}

\author{
Shaun R. McCann ${ }^{1}$ \\ Received: 11 April 2019 / Accepted: 11 April 2019 / Published online: 14 May 2019 \\ C) Springer Nature Limited 2019
}

I drink champagne when I win, to celebrate... and I drink champagne when I lose, to console myself.

Napoleon Bonaparte (1769-1821), French statesman and military leader

Haematopoietic cell transplantation (HCT) received its real impetus following the experiments in Los Alamos during World War II [1] and became widespread after the seminal publications by E Donnall Thomas and colleagues in the 1970s. The idea of corneal transplantation apparently originated with our old friend Galen (130-200 AD) [2], but the success of contemporary corneal transplantation owes much to 19th-century doctors, including Franz Reisinger, Wilhelmus Thorne and Samuel Bigger. Both modalities are now well-established medical procedures, although corneal transplantation is more widely available than HCT and is also more successful.

Have you ever met a person who had lost their sight because of a flying champagne cork? I once met such a man. He lost the sight in one eye having been struck by a champagne cork and unfortunately later developed retinitis pigmentosa (RP), resulting in loss of sight in the other eye. A severe price to pay even for a good glass of champagne! Although a relatively rare event, eye injuries sustained from flying champagne corks can be devastating and occasionally require corneal transplantation. They include rupture of the eye wall, acute glaucoma, retinal detachment, ocular bleeding, dislocation of the lens and damage to the eye's bone structure. As Ross Lyndall wrote in the London Evening Standard in December 2012: 'he (who had been struck by a champagne cork), is recovering well...but may need a corneal transplant'.

Shaun R. McCann

shaunrmccann@gmail.com

1 Haematology Emeritus, University of Dublin, Trinity College, Dublin, Ireland
To avoid such injuries a few rules should be followed. Try to be sober when opening the bottle. Make sure the champagne is well-chilled, which decreases the chance of the cork 'flying out' of the bottle. Point the bottle away from yourself and others, and remove the foil covering the cork. Undo the wire keeping your thumb on the cork. Hold the cork and wire tightly and gently rotate the bottle (this reduces the chance of the cork breaking). The cork should come out with a gentle 'sigh'. Remember the pressure inside the bottle may be 90 pounds per square foot and a cork may fly at 50 miles per hour.

While attending the annual meeting of ASH in San Francisco, my wife and I took a wine trip to Napa and Sonoma. We stumbled on the Korbel Winery near Guerneville in the Russian River Valley in Sonoma County. It was founded in 1882 by three Czechoslovak brothers named Korbel, and purchased by Adolph Heck in 1954. Heck's son, Gary, took over in 1984, and over time increased production from 150,000 to 1.3 million cases per year, making Korbel one of the largest wineries in the United States. The vineyard specialises in making a sparkling wine made by the so-called méthode champenoise, i.e. secondary fermentation takes place in the bottle.

Champagne, originally discovered by the monk Dom Pérignon, is a sparkling wine made from a blend of Chardonnay, Meuniere and Pinot Noir grapes (Blanc de Blancs is made from Chardonnay only). Dom Pérignon was favoured by James Bond (007) and he liked the 46 vintage in the film 'Moonraker'. Stephen King, in the film 'Misery', drank Dom Pérignon (vintage not specified) when he finished writing the book. Vintage Champagne is very expensive, but other sparkling wines like Franciacorta (Lombardy, Italy) and Cava (Catalonia, Spain) are not and make a very pleasant aperitif. Sparkling wines from Franciacorta are made from a blend of Chardonnay and Pinot Nero and the label 'Satèn' means the wine is made from Chardonnay only (Fig. 1). In Europe only wines made in the Champagne area can use the designation 'champagne' or méthode champenoise on the label. Sparkling wine from Korbel (they call it champagne) was served at the inauguration lunch for President Barak Obama. 
Fig. 1 A bottle of Franciacorta
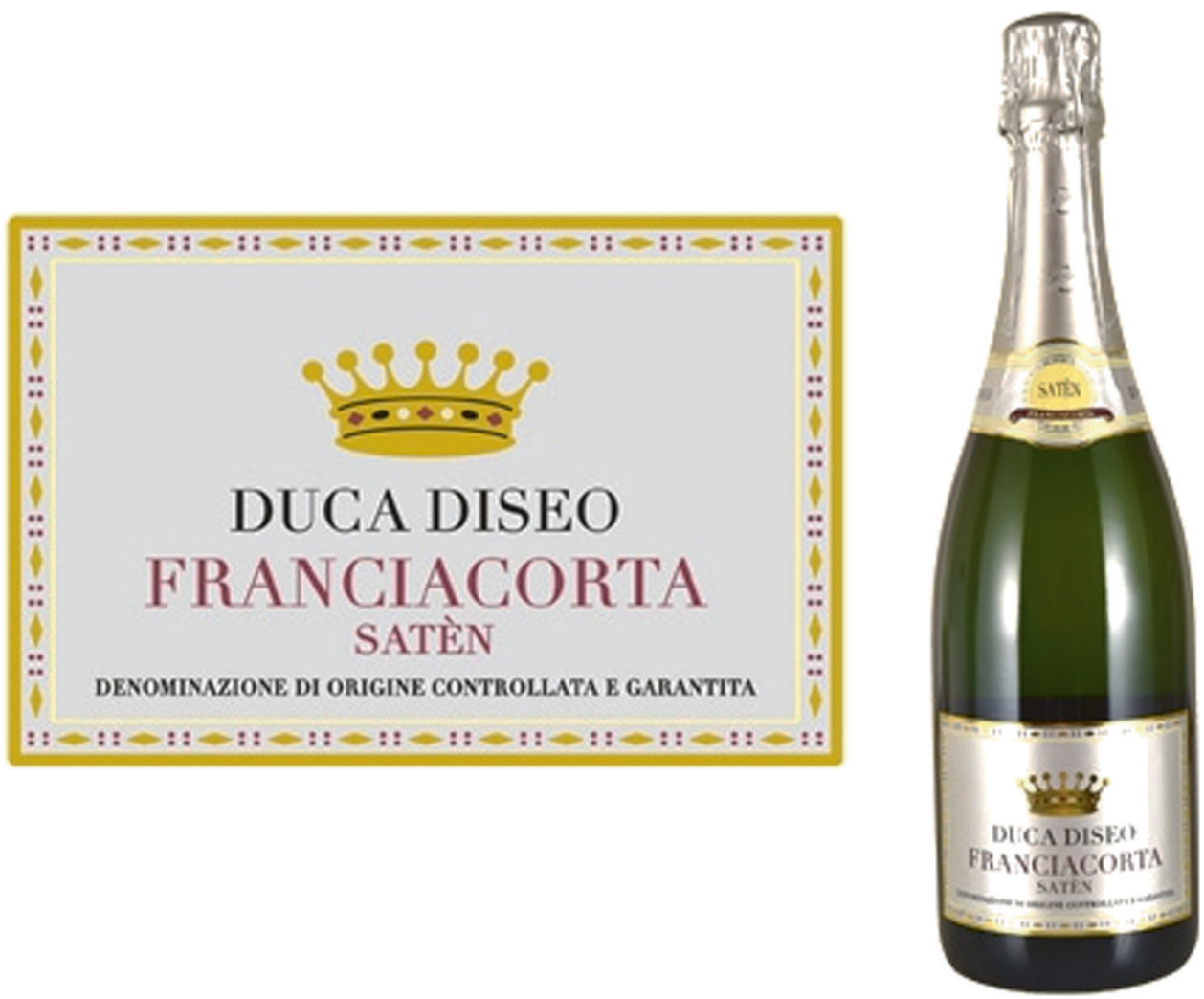

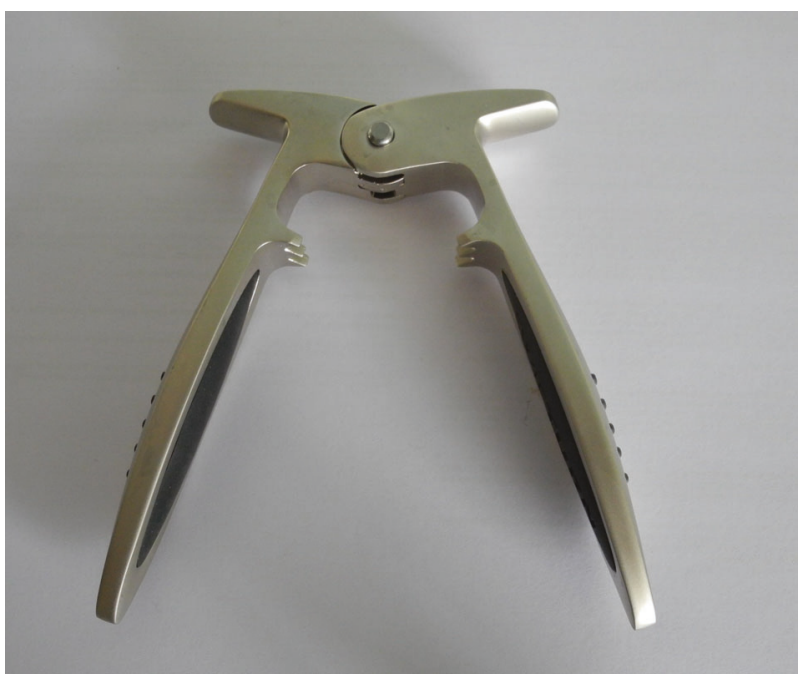

Fig. 2 A champagne opener from Korbel: it works!

Apart from sampling the wine at Korbel, I picked up an instrument for extracting corks and hopefully avoiding eye injury (Fig. 2). Remember the quickest way to cool champagne or any wine is to put it in a bucket with ice and water. Heat/cold travels quicker through water than air (thermal conductivity)!
Apparently, there is an Israeli vineyard opposite a Persian one in Napa Valley (personal communication Hillard Lazarus) and of course the Hochar family have been making wine, Château Musar, in the Beqaa Valley since 1930. It's a pity some of the politicians couldn't exchange bottles of wine instead of rockets and bullets.

In the meantime, I'll try to avoid flying corks, a corneal transplant or an HCT.

\section{Compliance with ethical standards}

Conflict of interest The author declares that he has no conflict of interest.

Publisher's note: Springer Nature remains neutral with regard to jurisdictional claims in published maps and institutional affiliations.

\section{References}

1. McCann Shaun R. A history of haematology: from herodotus to HIV. UK: Oxford University Press; 2016. ISBN: 978-0-19871760-7

2. Crawford AZ, Patel DV, McGhee CNJ. A brief history of corneal transplantation: from ancient to modern. Oman J Ophthalmol. 2013;6(Suppl 1):S12-17. 